\title{
marketing.
}

\section{Country Brand Equity Model: Sustainability Perspective}

\author{
Milivoj Teodorović, Jovan Popesku
}

\begin{abstract}
This paper proposes a model of country brand equity that incorporates the issue of sustainability in determining destination brand equity. In particular, the model includes elements of sustainability as its core dimensions and promotes the concept of the country sustainability promise that transforms destination resources into the positive perception and experience. The theoretical model is empirically tested using global secondary data confirming that country image is the most important element followed by sustainability and loyalty. Also, the analysis suggests the existence of the higher order construct confirming the country brand equity concept. Based on the research findings, the article offers some implications to the destination managers by suggesting the direction for further development and strategy implementation.
\end{abstract}

Keywords: country brand equity, sustainability, country brand loyalty, country brand image
JEL klasifikacija: M31, Q01

\section{INTRODUCTION}

A recent interest in country branding reached considerable levels by academic, research and professional communities (Ashworth et al., 2010; Cevero, 2013; Fetscherin, 2010; Szondi, 2007; Kotler \& Keller, 2012; Dinnie, 2008; Gertner, 2011; Go et al., 2011; Warnaby et al., 2013). As the global economy becomes a paradigm for competition and exports, the role of country branding becomes more apparent (Marruti \& Tench, 2015). Every brand projects its image into the market by either communication or marketing activities (Kotler \& Keller, 2012) or by the previous exposure to the brand (Kapferer, 2004; Shimp, 2007). Consequently, country brands gain their global position by just being there or by executing their country branding strategy (Marruti \& Tench, 2015). Inevitably, countries reflect their populations' image and are a major source of the national pride of their inhabitants (Marruti \& Tench, 2015). Consequently, citizens personify themselves with the reputation of their country (Cevero, 2013) causing the identity of country brand image to become strong reflection of the overall country brand equity.

At the same time, every country projects image of its people (Kotler \& Keller, 2012; Anholt, 2007). Because countries provide a bridge between information and economic impact, they are brands and, therefore, must be dynamic in nature and change their perception to achieve their global positioning goals (Anholt, 2007; Dinnie, 2008; Lindemann, 2010; Sevin, 2011). Consequently, country brand strategists face an ongoing challenge to constantly question, change and improve reflection of the images of their countries to maximize their global positions (Marruti \& Tench, 2015).

Because of the complex, global and comprehensive impact, a country has been chosen as the place for research in this paper. Besides, in this paper, we use interchangeably "country", "destination" and "national" brand (Fetscherin M, 2010). A number of researches consider national branding in political, diplomatic and economic scenarios, while governments are basically interested in the context of diplomacy and international relationships when promoting a country (Jaffe et al., 2001; Anholt, 2007; Jansen, 2008; Rojas-Méndez, 2013; Aronczyk, 2013). National branding 
is considered more appropriate in the context of public funding and project studies sponsored by international trade and development institutions such as World Bank, United Nations, International Monetary Fund and many others (Jansen, 2008). The others consider "place branding" to be an established and credible term for research (Lucarellli \& Brorström, 2013).

This paper supports country branding as place branding, in both concept and theory, which is supported by many researches (Rainistro, 2003; Kavaratzis, 2005; Dinnie, 2008; Moilanen et al., 2009; Maheshwari, 2010; Ashworth et al., 2010; Sevin, 2011; Go et al., 2011; Gertner, 2011; Ruzzier et al., 2013). Country branding, in the context of place branding, represents a dynamic subject in both research and management domains (Chan \& Marafa, 2013). There is a consensus among many academics, researchers, scholars and marketers that country brands are essentially the same as place brands. Therefore, many activities for communication and marketing strategies can be applied in combination with place branding activities (Dinnie, 2008; Gertner, 2011; Kotler et al., 2013). Consequently, country brand research can incorporate place image from the perspective of perception, experience, satisfaction and value from either customers, stakeholders or marketers' point of view (Anholt, 2007; Kavaratzis, 2010; Chan et al., 2013). Recently, with expanding globalization, country brand development has gained a significant attention from academic, research and corporate communities in the last decade (Dinnie, 2008; Ashworth et al., 2010; Go et al., 2011; Gertner; 2011; Warnaby et al., 2013; Kotler et al., 2012).

The ongoing trend and effort in the tourism destination industry is to give a new meaning to the destination competitiveness. Destination competitiveness models are being constantly evaluated, improved and modified in order to better match, deliver and communicate the value of a destination (Crouch, 2011; Dwyer, et al., 2014). At the same time, to modern marketing strategists, tourism destinations are brands and, therefore, subject to brand equity evaluation and management (Lindemann, 2010; (Keller, 2013; Marruti \& Tench, 2015; Kladou et al., 2015). On the other hand, we have a strong global trend to more efficiently manage our planet's resources in a holistic and sustainable manner (Ritchie \& Crouch, 2003, 2010; WWF, 2014; Kerk, 2015). Today, the trend of global awareness of sustainability has become both challenge and opportunity for businesses to gain upper hand in the marketplace (Castellani \& Sala, 2010; Gerlach \& Witt, 2012; SSF, 2014; Andersen, et al., 2013).
Although there is a significant body of knowledge on country branding constructs, the subject is still in the domain of "unlimited theory" (Marruti \& Tench, 2015). The reason lies in the fact that country destination brands are still a very much controversial and complex subject (Marruti \& Tench, 2015). Moreover, Buhmann and Ingenhoff (2013) noted that, in order to construct a model that will entirely capture aspects of the country brand equity, it is necessary to add dimensions on beliefs of aesthetic values of the country that will capture the country's attractiveness of its cultural and scenic aspect. Similarly, many scholars believe that country branding is a multidimensional construct (Ashworth et al., 2010; Gertner, 2011; Go et al., 2011; Buhmann et al. 2013; Dinnie, 2013; Lucarelli et al., 2013; Warnaby et al., 2013); however, not every analyst is looking at the same factors in the same way (Rocha, 2015). Also, there is no single valuation method that can be used reliably in determining the country brand value (Sinclair \& Keller, 2014).

The paper makes a contribution towards conceptualizing a model that captures the phenomenon of country brand equity, a value that a country obtains as a result of the consumption of its tangible, intangible, internal, external, functional, emotional and symbolic values as well as from the benefits that visitors are promised to receive during the consumption process. The focus of the paper is to present an extended version of the Dinnie's (2008) nation-based brand equity model that incorporates elements of sustainability. In the paper, the proposed extended model is referenced as the country brand equity model (CABE). The CABE model facilitates better understanding of the causal relationships between sustainability elements on one side, and the image, loyalty and ultimately the brand equity of a country on the other. The research encourages integration of the sustainability elements into the CABE model structure.

\section{SUSTAINABILITY AS A PROMISE}

According to the Global Network Footprint sustainable human development is achievable if the people can have accomplished lives without deteriorating the Earth (GFN, 2015). According to the same report, ecological footprint and human development index are the two key indicators for helping the humanity to achieve that goal (GFN, 2015). Sustainability, expressed by social and environmental measures, is recognized as one of the key indicators for assessment of tourism competitiveness (Dupeyras \& MacCallum, 2013). In order 
to better understand the influence of sustainability on the brand equity of a destination, there is an attempt to create a model that would test selected set of elements of sustainability and destination brand equity against indicators from the industry's macro and micro domains (Crouch, 2011; Dwyer et al., 2014).

According to Ritchie and Crouch (2010), each destination has its carrying capacity suggesting the implicit and explicit limitation of the resources to withstand, support and satisfy the various visitors' demands. The city of Venice, for example, is particularly under the threat for exceeding its carrying capacities (Simkins \& Peterson, 2015). However, limitations have positive and sometimes stunning effect on increasing brand equity (Simkins \& Peterson, 2015).

Brand equity maximizes value when it effectively and efficiently utilizes sustainability elements. For many, this is and will remain the ultimate goal in developing strong brands and maximizing their brand promise potential (GFN, 2015). As a starting point, we consider a relationship between brand equity and measures of sustainability such as ecological footprint and human development index. Human development index is a measure of vulnerability and resilience of humans to events that have significant impact on deteriorating their well-being, quality of life, progress and environment. However, the ability to cope and adjust, referred to as resilience, plays crucial part in the ability to withstand the negative results of the shocks caused by the sudden and destructive events that often require major human sacrifice to overcome. Brands that are more prepared and adjustable are thought to be more resilient (UNDP, 2014, p15).

There is no single method of measurement that exhaustively evaluates sustainability for each and every scenario that is globally accepted (Evans et al., 2015). Also, sustainable development cannot be measured by traditional economic models such as growth per capita income or GDP, which distort the reality in the distribution of the population wealth, when, in fact, the poor become poorer despite an increase in the average GDP (Evans et al., 2015). An interesting point has been made that social desirability is not necessarily the same as sustainability (Evans et al., 2015). There are other authors who suggest that each sustainability model has limitations, mostly due to lack of theoretical support and focus on large number of parameters (Nourry, 2008; Alfsen \& Greaker, 2007).

There are many different approaches for valuation and quantification of sustainability (Evans et al., 2015). Many agree that it would be difficult to obtain a specific measure by using one aggregate indicator
(Alfsen \& Greaker, 2007). Therefore, it is better to customize the measurement by selecting the most appropriate indicators to match the specific area of interest (Alfsen \& Greaker, 2007).

Recent trend shows that sustainability as a direction for businesses is gaining momentum among industries, markets, organizations, stakeholders, product managers and consumers (Petrenko, 2015). Indicators such as carbon, ecological, water, biosphere footprints are gaining more attention by the younger generations and increasingly more by the environmentally conscious consumers (Petrenko, 2015). Other arguments suggest that sustainability cannot be measured only by an increase in GDP and personal income (Evans et al., 2015). Rather, it has to include social variables (Evans et al., 2015). Even though the major assets for measuring sustainability evaluation are clean air, availability of clean water, climate and biodiversity, a significant attention must be given to natural, human and social capital (Evans et al., 2015).

The Ecological or Environmental Footprint Index denotes the demand of humanity for planet resources expressed in global hectares. The Ecological or Environmental Footprint is a measure of the land area with an average capacity to produce resources and absorb waste in order to sustain the human existence. The area available for human demands is called bio-capacity. Deforestation, erosion, flooding, overfishing, lowering land productivity and etc. reduce the bio-capacity (NFA, 2015). According to 2011 data, each person had 1.7 global hectares of the bio-capacity to go around (NFA, 2015). At the same time, the average needs of each person, according to 2011 data was 2.65 global hectares, suggesting that humanity needs 1.5 planets to satisfy its annual needs (NFA, 2015). In other words, the humanity lives beyond its means (NFA, 2013). The number of required Earths increases with the per capita consumption and the population and goes down with the efficiency in using the resources and the availability of the bio-capacity (Evans et al., 2015). The ratio between Ecological Footprint and Bio-Capacity Footprint needs to be below one to achieve sustainability (NFA, 2013; Evans et al., 2015; Moran, et al., 2008). In spite of its widespread use and popularity, the Ecological Footprint Index has its drawbacks primarily because (1) multiple data are converted into land area, (2) it doesn't include irreversibility, and (3) it shows positive performance even if it exceeds environmental boundaries (Nourry, 2008). There is an argument that cities and highly urban areas cannot live within their ecological carrying capacity (Dietz \& Neumayer, 2007). 
The Biodiversity Footprint Index is an indicator of the ability of the nature to cope with the material metabolism caused by human economies (NFA, 2015). It represents, in aggregate, urban productive areas, natural resources, waste absorption, and water renewal. It is a measure of the biosphere's capacity to regenerate itself. Like the Ecological Index, the Biodiversity Index is expressed in global hectares (NFA, 2015). The Ecological Index divided by the Biodiversity Index gives the number of Earths or countries needed to fulfill the demands of the humanity.

On the other hand, Human Development Index (HDI), developed by the United Nations, tracks down the ability of the humanity to reduce vulnerability and build resilience to shocks and events which result from constant shifts in the social, economic, environmental and political spheres. The HDI measures three basic dimensions of human life: (1) healthy life and longevity, (2) learning capacity and (3) standard of living (UNDP, 2014). The 2011 UNDP report defines human development as "the expansion of the essential freedoms of people today while making reasonable efforts to avoid seriously compromising those of the future generations".

The 2014 UN report on human development argues that sustainable human development has to do with sustainability of peoples' choices, mostly in the social and economic domains. The key to human existence lays in their reliance on the bounty and resilience of the natural world. However, environmental degradation and climate change are impacting the long-term survival of the human race. Therefore, the focus of the human sustainable development is to balance the current choices of the humanity and the choices available to future generations (Evans et at., 2015). If the consumption exceeds the regenerative and absorbable boundaries of the planet, the longterm prosperity and existence will be jeopardized. The human development reports from 2011 and 2012 argue that environmental deterioration can slow down human development and even reverse it (UNDP, 2014). The same report further recognizes the positive correlation between the countries with higher HDI and the Ecological Footprint while pointing out that water consumption is unsustainable in all developing and developed countries.

The Sustainable Society Index (SSI) is a global indicator for measuring and studying the worldwide efforts of global societies in developing more sustainable levels of existence (Kerk \& Manuel, 2014). It was developed by the Sustainable Society Foundation and it covers 151 countries or $99 \%$ of the world population. It consists of 21 indicators, clustered in seven categories and three dimensions. Validity and reliability of the SSI data have improved over the years (Simkins \& Peterson, 2015). In 2014, the SSI was approved by the Joint Research Center of the European Commission as a valid data for measuring sustainability at the country level (Kerk \& Manuel, 2014; Simkins \& Peterson, 2015). The SSI index comprises three individual dimensions or indicators: Human Wellbeing, Environmental Wellbeing and Economic Wellbeing. The correlation between Environmental and Human Wellbeing shows strong but inverse relationship, meaning that an increase in Human Wellbeing is followed by a decrease in Environmental Wellbeing (Kerk \& Manuel, 2014). The same authors argue that Economic Wellbeing is a precondition for achieving Human and Environmental Wellbeing goals. So far, the SSI index has been used in many studies and research projects (Viswanathan et al., 2014; Mittelstaedt et al., 2014; Meng, 2015).

\section{COUNTRY BRAND MEANING}

Since 2001, there have been at least 64 relevant published papers on research in destination brand equity. However, the interest in destination brand image overshadows the interest in destination brand equity (Kladou et al., 2015). Since most of the theoretical and observable research has focused on defining and measuring brand equities of products (Konecnik \& Gartner, 2007) a lack of empirical research effort is evident when a service or destination industry is concerned (Boo, et al. 2009). As a result, there is an abundance of research and academic literature on destination brand image and very little on destination brand equity. In the recent years, interest in destination brand equity has intensified as researchers, marketers and analysts started to apply the brand equity constructs on destination valuation and analysis (Kladou et al., 2014), as proposed by Aaker $(1991,1996)$. Literature review revealed the pressure for credibility and substance causing the researchers, marketers and scholars to adopt the term "Destination Brand Equity" borrowed from the traditional corporate and customer branding theory (Kladou et al., 2015).

Out of the five components that Aaker's (1991, 1996) brand equity model proposes only four are actually used in the service context. Brand asset is not considered to be important in the destination context (Konecnik et al., 2007). However, because of the visiting performance, a customer-based brand equity 
concept is preferred (Gartner \& Ruzzier, 2011). A significant body of literature evokes identity and personality when referring to brands or even brand equity. Brand image is particularly popular among destination stakeholders, marketers and strategists, and for a good reason. Image of a destination articulates a convenient dimension in creating plans and strategies (Lee, Ju-Pak, \& Hong, 2015).

National brand is a strategic use of a nation's resources as a multi-dimensional bland of various elements with foundation in the national cultural domain that positions the country in the minds of the global pool of stakeholders and the population (Schröter \& Schwekendiek, 2015). National image can be evaluated and analyzed from the point of power, economic development, democracy, social stability, security, cultural attractiveness, rule of law and trade (Schröter et al., 2015).

Attractiveness and competitiveness of a destination is amplified by its cost-to-value ratio of its offers to visitors by creating a feeling in the visitors' heads related to the value factor of the destination offers that are either consumed or are expected to be consumed (Ritchie \& Crouch, 2010). Cost is a vital indicator of a destination's ability to create the expectation effect for future experiences as well as a satisfactory element of the past consumptions (Ritchie \& Crouch, 2010).

Country destination brands, like other brands, must project trust and strive to achieve a lasting positive relationship with their visitors (Mihailovich, 2006). From the global perspective, a country's reputation is its most valuable trade-mark asset for what it stands and offers to the potential visitors and stakeholders (Go \& Govers, 2011; Buhmann \& Ingenhoff, 2013). Globalization is a phenomenon that is taking place regardless of what countries, organizations, stakeholders and individuals do, act or perform. It affects macro and micro relationships and imposes different positioning strategies among countries (Parker, 2007). Globalization doesn't bring equality to countries but significantly affects the way countries interact, communicate, trade, coexist and influence opinions and attitudes about them by different stakeholders (Kavaratzis, 2010; Buhmann \& Ingenhoff, 2013; Vardar, 2013). Much attention has been paid to the use of a country's image as a tool to facilitate the country's development (Marruti \& Tench, 2015). Many scholars agree that nations should use country brand positioning to maximize their global market potential (Brand Finance, 2015)

Country branding requires more sophisticated and multi-dimensional branding approach than branding a product or a service (Dinnie, 2008; Moilanen et al., 2009; Kavaratzis, 2010; Warnaby et al., 2013). Country brand is a multi-level, multi-component, multi-dimensional, interdisciplinary and multi-disciplinary topic (Ashworth et al., 2010; Go et al., 2011; Gertner, 2011; Buhmann et al., 2013; Warnaby et al., 2013). Similarly, according to Fetscherin (2010, p.467), there is a common view that country brand belongs to the public domain.

Country brand is a source of national pride, national identity, a reflection of who we are, where we come from and what role in the global world we play (Buhmann \& Ingenhoff, 2013). It is a passport of the global citizenship that belongs to anyone (Dinnie, 2008). Also, the number, diversity and relevance of the stakeholders associated with country brands is not restricted to visitors, politicians, citizens, public and private officials, local community, researchers, scholars, marketers and etc. (Jansen, 2008; Kavaratzis, 2010; Ruzzier \& De Chernatony, 2013). An interesting point is made by Maheshwari (2010), who proposes a concept of "revitalized brand image". Country branding goes along with government interests, political strategies and organizations responsible for positioning country brand at the global level (Marruti \& Tench, 2015).

Dinnie (2008) observes country brand as a much politicized subject that is affectionately guarded and quite often causes contending views and points. According to Marruti and Tench ( 2015) there is a continues improvement by governments to make country brands more sophisticated (Kavaratzis, 2005; Anholt, 2007; Dennie, 2008; Go \& Gover, 2011). The view is supported by a plethora of consultants, public and private agencies, public relations, practitioners, theoreticians, and communication specialists (Aronczyk, 2013; Zakarevičius \& Lonikaitè, 2013). Governments increasingly pay attention and fund development, promotion, management and performance of country brands since they (governments) consider country brands to be a vital supporting asset in negotiations, debates and political discussions (Anholt, 2007; Szondi 2007; Moilanen \& Rainisto, 2009).

On the other hand, marketing theory becomes an important ally in positioning country brand in the global tourism markets (Moilanen et al., 2009; Kavaratzis, 2005). Finally, there is a notion that no comprehensive, wide-range country branding model exists yet, despite a mass of literature and theoretical and conceptual models that is constantly increasing (Marruti \& Tench, 2015). Buhmann and Ingenhoff (2013) note that an effort to construct a model that will entirely capture all aspects of country branding it is nec- 
essary to include dimensions of beliefs in aesthetic values of the country that will capture the country's attractiveness of its cultural and scenic aspects. Many scholars believe that country branding is a multifaceted construct (Ashworth et al., 2010; Go and Gover, 2011; Gertner, 2011; Buhmann et al., 2013; Dinnie, 2013; Warnaby et al., 2013; Lucarelli et al., 2013).

Country destination brand equity is a rapidly evolving construct conceived as a spin-off from the more established product such as corporate brand equity (Kladou et al., 2015). In order to globally position a country, based on its perceived image, a number of brand models have been considered (Fabiutti \& Tench, 2015). The most interesting ones are The Anholt GfK Roper Nation Brand Index ${ }^{\mathrm{SM}}$, The Future Brand Country Brand Index, Brand Bonding Spectrum-BBS and CBSI Country Brand Strength Index (Fabiutti \& Tench, 2015). Other indices for measuring destination images are the Competitiveness Index by World Economic Forum, the Human Development Index, GDP, and other UN's statistics that are used for that purpose.

Further, Fabiutti and Tench (2015) note that tourism is identified as a major dimension in all presented brand models followed by immigration, governance, exports, culture and heritage, economy, investment and people. On the other hand, sports, science, technology, quality of life and value system have been less associated with country brands. Perceptions and attitudes, though not explicitly mentioned in any of the evaluated brand models, are considered to be an intrinsic part of any country brand model (Fetscherin, 2010; Dupeyras et al. 2013).

According to the OECD Tourism Committee, the future-oriented indicators, in addition to the current and past ones, should be deemed a better measure of competitiveness of tourism destinations (Dupeyras \& MacCallum, 2013). The difficulty in selecting and identifying the core indicators is stated as a reason for that. An interesting point is made on importance of the foresight in decision-making processes regarding destination competitiveness in the future. The OECD recognizes that the policies of the future will not be the same as those in the past (Dupeyras \& MacCallum, 2013). Among the proposed measurement aspirations are brand awareness, sustainability, behavior, motivation, satisfaction and etc. (Dupeyras \& MacCallum, 2013). The OECD suggests using the Tourism \& Travel Competitiveness Index and Nation Brand Index (Dupeyras \& MacCallum, 2013). They argue that many countries do not have adequate index measurement systems in place.
To track their image, reputation and profiles, most of the countries use the Travel \& Tourism Competitiveness Index (WEF, 2015) and the Country Brand Index (FutureBrand, 2015; Dupeyras \& MacCallum, 2013). However, only a few countries have put in place country-to-country competitiveness measures to track their position in the global tourism markets. Furthermore, the ideal number of indicators may vary from country-to-country (Dupeyras et al., 2013). The OECD suggests at least eleven core and nine supporting indicators, but the final mix differs by the particular model a country adopts (Dupeyras et al., 2013). Moreover, a country's brand image and reputation can be tracked and measured using the Travel \& Tourism Competitiveness Index (WEF, 2015), the Human Development Index (UNDP, 2014), Gross Domestic Product (GDP), the Gallup poll and the United Nations statistics (Marruti \& Tench, 2015).

There is a significant amount of literature devoted to country brand models either from business or research perspective. From the business point of view, evaluations are done to identify business performance of a country brand, receipts, ranking, improvements and image levels, as well as the public impression of a country (Buhmann \& Ingenhoff, 2013; Marruti \& Tench, 2015). Also, different models compare different variables and dimensions, which have business or research significance. From the holistic point of view the models should consider variables and elements that correspond to internal, integrated, relationship and performance dimensions of the general holistic model (Kotler \& Keller, 2013).

\section{COUNTRY BRAND EQUITY MODEL}

The process of formatting country brand equity model $(\mathrm{CABE})$ is presented in Figure 1. The proposed conceptualization is based on Dinnie's (2008) view on the national brand equity model (NBEQ) which consolidates tangible and intangible, internal and external assets and liabilities of a nation. The CABE model supports both consumer and financial (economic) perspective. The rational for basing the CABE model on the Dinnie's NBEQ model rather than on more publicized customer-based brand equity models, such as Keller's or Aaker's one, is the universality and generality of the NBEQ model which is considered more appropriate for the development of a multifaceted, multi-level, multi-component, multi-dimensional, interdisciplinary and multi-disciplinary country brand equity model (Ashworth et al., 2010; Go et al., 2011; 


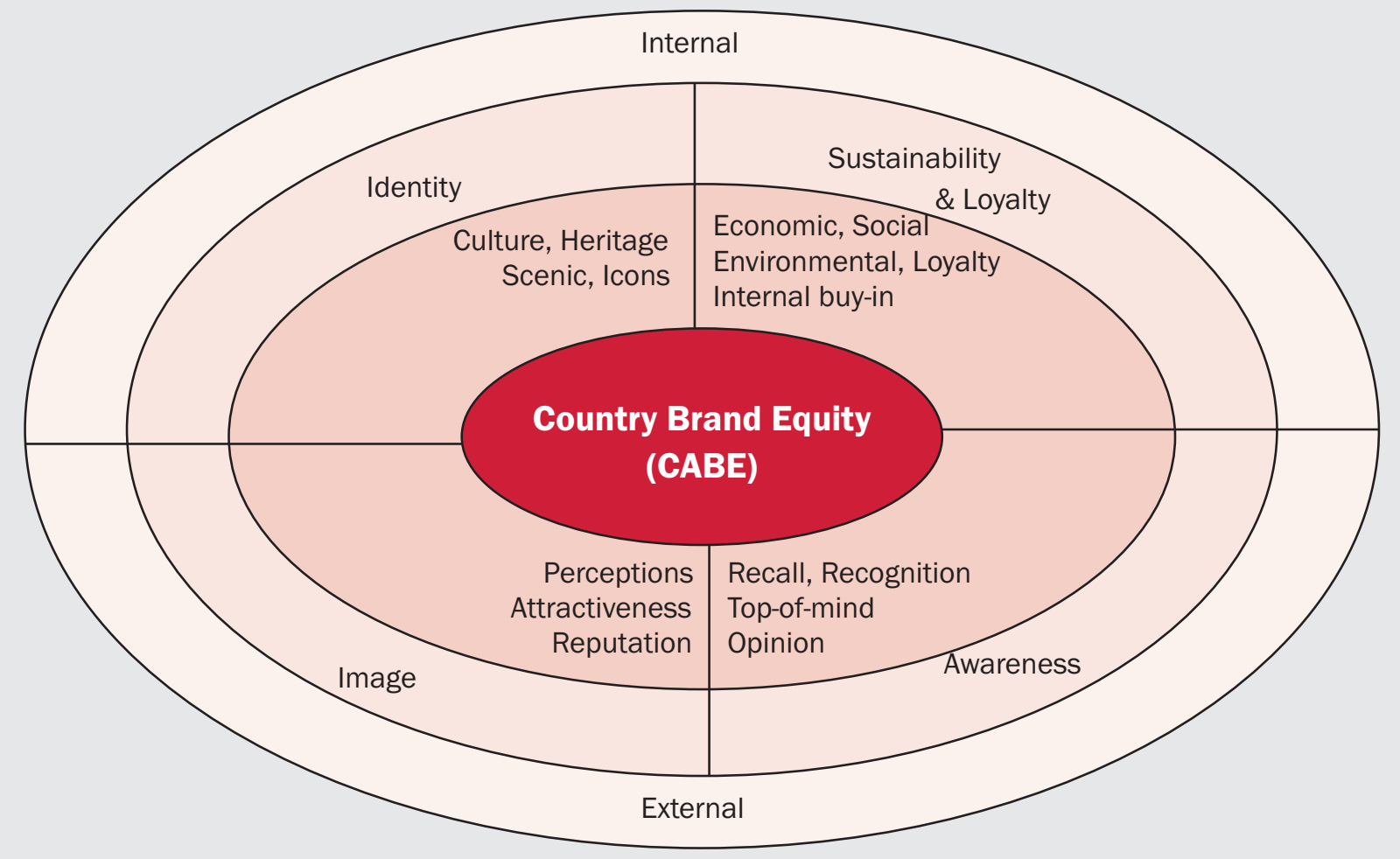

Gertner, 2011; Buhmann et al., 2013; Warnaby et al., 2013).

The paper makes an argument that a country, as a brand, shows the ability to (1) deliver value to customers, (2) provide process for value consumption and (3) stimulate visitors to come back and repeat the experience. Thus, this research proposes that country image, awareness and identity along with the elements of sustainability, such as environmental, human and economic ones constitute the core elements of the country destination brand promise as shown in Figure 1.

Furthermore, the study proposes the CABE model as a multidimensional construct which depicts the process of building a relationship between visitors and a country brand, as proposed by Dinnie (2008). Hence, we suggest two dimensions and four constructs as building blocks of the CABE model as shown in Figure 1. According to the proposed model the brand equity sources come from internal and external assets. The internal assets comprise of national identity and both sustainability and loyalty assets while the external assets support image perceptions and awareness.

\section{Identity}

The national identity assets represent unique value of the country, its authentic country promise that has evolved over a long period of time. Country brands are created as functional, symbolic and emotional values of a destination, endorsed by the benefits visitors are promised to receive as a consequence of the offer consumption (Gnoth, 2007). This position is in line with the value co-creation and with the perceived value of a destination. A country sells its cultural, social, natural resources to its visitors with an intention to match and satisfy the visitors' expectations. Therefore, countries as destinations serve as a marketing battleground for absorbing visitors' response.

The country's scenery, traditional culture as well as their unique visual images, symbols and other authentic elements can serve as powerful differentiation sources for the nation brand. The sources for identity assets are not marketing induced or created but represent true manifestations of what a country really is (Dinnie, 2008). 


\section{Sustainability and Loyalty}

Sustainability and loyalty assets denote a country's efforts to make its environment prosperous for brand equity development. These include both loyalty levels and sustainability elements. The CABE model is based on assumptions that sustainability is (1) promised by a country through a country as a brand, (2) co-created by both a country and a visitor, and (3) evaluated by a visitor. The latter is based on the change in the state-of-being as a result of interactions with a country brand. The relationship relies on Grönroos (2009) and Lindberg-Repo et al. (2004) studies which emphasize that, besides functional characteristics of products and services, the employees involved at the point of service, other customers, competitors and media, all play part in an articulation of the brand promise.

The sustainability elements are incorporated into the CABE model as an internal country buy-in or promise. Sustainability has been recognized as both national asset and a process for creating national brand equity (Gartner, 2014). Therefore, through its major dimensions, human, social and economic sustainability is a reflection of a country's value, its people and culture.

The human well-being dimension reflects a potential impact on the perception of a country as a destination from the perspective of human basic needs, health, personal and social development. As a result of visiting a country, a visitor develops a certain state of being. As pointed earlier, a value for a customer is created in a hierarchical and energetic process of consumption of attributes and resources that result in gaining experience and satisfaction. Knowledge, emotional and social value dimensions are recognized as the elements influencing customers' judgment and feelings. Positive psychology regards the past experience as the well-being dimension (Seligman \& Csikszentmihalyi, 2000).

On the other hand, the economic well-being influences a visitor's judgment and feeling about the country's standard of living, developed infrastructure, safety, ease of doing business, openness, corruption, risk and etc. These attributes are tracked by many global agencies and organizations in the form of various country indexes such as the HDI, GDP, employment, imports, exports, financial indexes, and etc.

On the other hand, country destination brand loyalty, both attitudinal and behavioral, represents the ultimate goal in the country destination brand equity development. According to the previous literature review, brand loyalty, in general, is considered to be the way visitors attach themselves to the country. Behavioral loyalty is manifested in the intention to come back, positive opinions and referrals (Konecnik et al., 2007). On the other hand, attitudinal loyalty perceived as (1) willingness to revisit and recommend a country as a destination, (2) explicit preference for a country and (3) readiness to pay a premium price (Konecnik et al., 2007; Boo et al., 2009; Chen et al., 2010; Pike et al., 2011; Ferns et al., 2012; Im et al., 2012; Horng et al., 2012; Bianchi et al., 2014).

\section{Image}

Country destination image is reflected in tangible and intangible resources offered to a potential visitor for consumption. Each visitor has its own mix of experienced and expected resources (Moeller, 2010; Zabkar et al., 2010). Human, tangible and intangible resources for tourism consumption are exhaustively covered by the literature (Konecnik et al., 2007; Chen et al., 2010; Ferns et al., 2012; Horng et al., 2012; Im et al., 2012; Bianchi et al., 2014;). It is perceived that quality and attribute-based image represent performance, social and intangible resources of a country as a tourism destination in the CABE model. Therefore, it is expected that measurement and conceptualization of both entities overlap. On the other hand, many studies show high correlations between image and quality (Konecnik et al., 2007; Ferns et al., 2012).

The present day reality of a nation can be severely altered by perceptions of the either positive or negative image that people may incur about a country. Therefore, it is important for countries to have a system for monitoring, evaluating and managing country image perceptions effectively. On the other hand, the positive image of a country can increase its exports, interest in visiting, investments and reputation Anholt (2007).

\section{Awareness}

A country needs to disseminate information about its assets if it is to create positive attributes that it wants to project. The country brand awareness represents recall and recognition information strength in the minds of visitors. Recognition reflects an ability of a prospective tourist to recognize the country in the consideration set based on the previous exposure to the country. Recall, on the other hand, is the ability to associate the country's name with a particular category (e.g., skiing, swimming, gaming, hiking, shopping, etc.). Similarly, according to Aaker (1996), opinion is the highest le- 
vel of awareness reflecting countries' reputation and good name (Konecnik et al., 2007; Boo, et al., 2009). Today's use of social and booking media further influences potential visitors' perception and communication behavior (Xiang \& Gretzel, 2010). In addition, in order to create a positive impact on the country brand equity, brand awareness of the country as a destination must be positive (Gartner, 2009).

\section{HYPOTHESES DEVELOPMENT}

The relationships between visitors' perceptions of destination promise with destination brand equity and destination awareness were empirically confirmed by (Pike et al., 2011; Chen et al., 2010; Kladou et al., 2014). A strong destination brand awareness influence on quality and image is confirmed by Pike et al. (2011) and Kladou et al., (2014), while Chen and Myagmarsuren (2010) confirm the relationship with the attribute-based image. Earlier studies combined the image concept with other dimensions. For example, Bigne et al. (2001) relate image to quality and loyalty dimensions in both attitudinal and behavioral context. Therefore, it is clear from the previous study that the relationships of the whole concept of CABE should be confirmed. Consequently, we formulate the first two hypotheses:

\section{H1: Proposed dimensions of the CABE model are posi-} tively and significantly related.

H2: The stronger a country's destination awareness, the stronger a country's image.

Aaker (1996) suggests that brand loyalty represents a central element of the brand equity. On the other hand, Keller (2013) suggests the image as a major component from the customer perspective. Other authors (Yasin et al., 2007; Shahin et al., 2012; Moradi et al., 2012) provide empirical evidence that the national destination image is an important source of the knowledge about a country for the visitors to form perception about that country as a destination. Further, the following set of hypotheses is proposed:

H3: The stronger the country's image, the more significant perception of the human well-being.

H4: The stronger the country's image, the more significant perception of the environmental well-being.

H5: The stronger the country's image, the more significant perception of the economic well-being.

According to Konecnik et al. (2015), sustainability elements make vital part of the country brand. The authors support using elements of sustainability as core concept of brand identity. Similarly, Belz (2008) elaborates on significance of building a sustainable interface with customers. Also, Belz et al., (2010) stress that creating social and environmental value increases customer value. Based on the literature review, a reasonable conclusion can be drawn that sustainable concepts can be substantially incorporated into all elements of brand identity as well as in the visible and invisible parts of the country brand (Konecnik et al., 2015). Following these observations, we include the following hypotheses:

\section{H6: Elements of sustainability have a significant effect} on the CABE.

H7: The country image makes a core element of the $C A B E$ model and accounts for the highest loadings of variance of any of the related variables.

\section{METHOD}

This research is based on the secondary global country data obtained from the global database sources as shown in Table 1. The use of secondary databases for analysis of country destination brand equity is supported by Busse (2010), Simkins et al. (2015) and Chigora, (2015). In this study, both perceptual and real or historical data are used which is justified by the dual customer and financial (economic) perspective of the CABE model.

Simpkins et al. (2015) argue that secondary data has several advantages over primary data. These include (1) more readily available, (2) less costly to obtain, (3) less time intensive, and (4) highly relevant. Despite those advantages, there are issues with validity and reliability of data. However, large secondary data sources such as global indexes, which come from reputable sources, in general are considered highly reliable (Simkins et al.,2015).

The number of countries with the data for specific variables ranged from 51 to 182 . Only 37 out of 182 countries had no missing data for all variables, an equivalent to answering all the questions in a survey. A proportion of missing data was higher for variables that show intangible attributes such as the Reputation Index (51), the Country Risk (54), the Attractiveness (77) and the Awareness (77). This can be attributed to the size limitation of each index. Consequently, the missing data issue was addressed.

The ten percent of missing data was used as a cutoff to divide the data into two groups. The first one, 
TABLE 1. List of Variables

\begin{tabular}{|c|c|c|c|c|}
\hline Dimensions & Scale & Variables & Data Source & $\begin{array}{c}\text { \# of } \\
\text { Countries }\end{array}$ \\
\hline \multirow{2}{*}{$\begin{array}{l}\text { Awareness } \\
\text { (External) }\end{array}$} & AW 1 & Awareness & Travel Image & 77 \\
\hline & AW 2 & Reputation & Reputation Institute & 51 \\
\hline \multirow{5}{*}{$\begin{array}{c}\text { Image } \\
\text { (External) }\end{array}$} & $\mathrm{IM} 1$ & Attractiveness & Travel Image & 77 \\
\hline & $\mathrm{IM} 2$ & Corruption Perception Index & Transparency International & 161 \\
\hline & $\mathrm{IM} 3$ & Consumer Price Index & Numbeo & 110 \\
\hline & IM 4 & Travel \& Tourism Competitive Index & World Economic Forum & 129 \\
\hline & IM 5 & Country Risk & Trading Economics & 54 \\
\hline \multirow{12}{*}{$\begin{array}{l}\text { Sustainability } \\
\text { (Internal) }\end{array}$} & SU 1 & Economic Well-being & Sustainable Society & 146 \\
\hline & SU 2 & Environmental Well-being & Sustainable Society & 146 \\
\hline & su 3 & Human Wellbeing & Sustainable Society & 146 \\
\hline & SU 4 & Biocapacity Footprint & National Footprint Foundation & 182 \\
\hline & SU 5 & Ecological Footprint & National Footprint Foundation & 182 \\
\hline & SU 6 & Human Development Index & UNDP & 170 \\
\hline & SU 7 & Local Purchasing Power & Numbeo & 110 \\
\hline & SU 8 & GDP per Capita & National Footprint Foundation & 182 \\
\hline & SU 9 & GDP from Tourism & World Data Atlas & 151 \\
\hline & SU 10 & GDP per Tourism per Arrival & World Data Atlas & 134 \\
\hline & SU 11 & GDP per Tourism per Capita & World Data Atlas & 149 \\
\hline & SU 12 & Population & National Footprint Foundation & 182 \\
\hline \multirow{6}{*}{$\begin{array}{l}\text { Loyalty } \\
\text { (Internal) }\end{array}$} & LO 1 & National Brand Strength & Brand Finance & 90 \\
\hline & LO 2 & National Brand Value & Brand Finance & 90 \\
\hline & LO 3 & Receipts per Arrival & National Footprint Foundation & 148 \\
\hline & LO 4 & Receipts & National Footprint Foundation & 148 \\
\hline & LO 5 & Arrivals & National Footprint Foundation & 148 \\
\hline & LO 6 & Index of Economic Freedom & Heritage Foundation & 163 \\
\hline
\end{tabular}

denoted as Case-50, consists of 58 countries with the missing data equal to or less than $10 \%$. The second set, marked as Case-170, consists of 167 countries with the number of missing data exceeding the ten-percent threshold. In both groups, the missing data were replaced by corresponding means as suggested by Hair et al. (2010). By expending the data set from 58 to 167 countries, and by allowing the higher percentage of missing data, we assumed all the limitations and special conclusions that came along with them. We justify this action with the intention of further exploring possibilities of producing more empirically-proven relationships among the potential constructs (Konecnik et al., 2007). A total of 25 variables is used and associated to the four basic dimensions of the proposed CABE model as shown in Table 1.

Country awareness is represented by two variables, Awareness and Reputation, obtained from Travel Image and Reputation Institute, respectively. Variables for country awareness were selected among the indicators that, according to Aaker (1991, 1996), closely match the six dimensions of the awareness dimension: recognition, recall, top-of-mind, dominance, brand knowledge and reputation. All variables have numerical data of a different scale.

Country image is presented by five variables. Intangible experience of a country is captured by the Attractiveness Index from Travel Image. However, more supportive and specific experience of a country is provided by the Corruption Perception Index, Country Risk and the Consumer Price Index. The tangible experience is fulfilled by the Travel \& Tourism Competitiveness Index (TTCI) which could be used to represent the country awareness dimension, too. All variables have numerical data of a different scale.

Next, sustainability is represented by twelve variables. Despite the fact that sustainability is a relatively recent addition to the destination brand equity research interest, this study supports sustainability as a significant experiential state of being (Gartner, 2014). Taking into account the overwhelming impact that sustainability could exhibit on the cognitive, emo- 
tional and co-native state of being, in the process of selecting a country as a destination, justifies the selection. The most significant impact is expected to come from the environmental and human elements of the sustainability model.

Economic perception is represented by the Economic Well-being variable from the Sustainable Society Foundation (SSF) and the Local Purchasing Power sourced from (Numbeo, 2016). The Environmental segment is represented by the Ecological and Biocapacity Footprints, and the Environmental Well-being, while the human impact is covered by the Human Development Index from the United Nations and the Human Well-being from the SSF. All GDP-based variables are considered to make part of economic sustainability. All sustainability variables have numerical data of a different scale.

Finally, country destination brand loyalty is represented by six variables. The study follows the previous findings of the destination brand equity research with the clear intention to (1) define country destination brand loyalty as the level of affinity that a potential visitor has with a country as a destination and (2) distinguish between attitudinal and behavioral loyalty (Gartner, 2009; Boo et al., 2009; Pike et al., 2011; Ferns et al., 2012; Kladou et al., 2014).

In this study, attitudinal loyalty is represented by the National Brand Strength Index from Brand Finance and by the Index of Economic Freedom sourced from Heritage Foundation. Attitudinal loyalty represents (1) the intention to revisit the country and recommend visiting that country to others, (2) preference choice of the country when comparing to other countries, and (3) willingness to pay premium price (Bianchi et al., 2014; Boo et al., 2009; Chen et al., 2010; Ferns et al., 2012; Im et al., 2012; Horng et al., 2012; Pike et al., 2011; Konecnik et al. 2007).

On the other hand, behavioral loyalty is concerned with the actual behavior of a visitor and is demonstrated by a repeated visit and positive word of mouth recommendations (Konecnik et al., 2007). In this study, we represent behavioral loyalty by Receipts, Arrivals, Receipts per Arrival and the National Brand Value Index from Brand Finance. All loyalty variables have numerical data of a different scale.

\section{RESULTS}

The exploratory factor analysis of the Case-50 data set, by using Principal Component Analysis, produced two factors explaining $65 \%$ of the whole variance with the significant Bartlett's test and an acceptable KMO (0.813), above the 0.7 threshold. The factor communalities are all above 0.3 levels with the loading factors in the Pattern Matrix above 0.6 levels. The Component Correlation Matrix shows positive and significant correlation of 0.594 between the two extracted factors.

The first factor construct, which explains $52 \%$ of total variance, has six independent variables. The first three independent variables (Receipts per Arrival, National Brand Strength and Index of Economic Freedom) are associated with loyalty while the other three (Ecological Footprint, Environmental Well-being and Economic Well-being) are mostly associated with sustainability. Hence, we can conclude that the first factor is associated with the "Internal" level of the CABE model as shown in Figure 1. Similarly, the second extracted factor, which explains $13 \%$ of total variances, loads three independent variables. The first two variables, TTCI and Attractiveness, we consider to be associated with image while the third variable Awareness represents awareness or salient level. Therefore, we conclude that the second factor closely resembles the "External" level of the CABE model as shown in Figure 1.

On the other hand, the exploratory factor analysis of the Case-170 data set, by using Maximum Likelihood with Varimax and Kaiser Rotation methods, produced twelve extracted variables with three distinct factor loadings. The analysis shows an acceptable KMO (0.752) with a significant Bartlett test. Extracted factor communalities resulted in the values higher than 0.3 , except for one variable. Also, the loading factors in the Rotated Factor Matrix exceeded the 0.4 value. The variables extracted explained $72 \%$ of the variances. The first factor, which explains $40 \%$ of total variance, has strong associations with loyalty. The second factor, which explains $19 \%$ of the variances, is strongly associated with sustainability, and the third factor, with the explanation factor of $13 \%$ of total variance, is related to image.

The confirmatory factor analysis was used to empirically test a dimensional connectivity of the proposed CABE model. The analysis produced a good model fit for the Case-50 data set and an acceptable model fit for the Case-170 data set, as expected.

The analysis of the nine variables extracted from the Case-50 data model produced all standardized loadings statistically different from zero. By eliminating Economic Well-being, the model fit was improved and passed higher on the recommended thresholds. Based on the Case-50 data set fit-statistics, all statisti- 
TABLE 2. Goodness-of-Fit Statistics

\begin{tabular}{|l|c|c|}
\hline Measures & Case-50 & Case-170 \\
\hline Chi-square/df (cmin/df) & 1.212 & 2.597 \\
\hline p-value for the model & 0.240 & 0.00 \\
\hline CFI & 0.986 & 0.955 \\
\hline GFI & 0.913 & 0.918 \\
\hline AGFI & 0.826 & 0.859 \\
\hline SRMR & 0.048 & 0.069 \\
\hline RMSE & 0.061 & 0.098 \\
\hline PCLOSE & 0.386 & 0.002 \\
\hline
\end{tabular}

cal values meet the criteria, except for the GFI which is slightly below the 0.95 threshold. On the other hand, the confirmatory factor analysis of the Case-170 data set reduced the initial set of twelve variables by two on validity issues. The fit statistics of the Case-170 data set shows p-value below the recommended 0.05 value, GFI and PCLOSE slightly under the threshold values, while RMSE is on the borderline (Hair et al., 2010). See Table 2.

Consequently, the goodness-of-fit statistics of p-value (0.0) and PCLOSE (0.002) makes the model acceptable, since we compromised between the number of countries and percentage of missing data in our data set (Konecnik et al., 2007). Exceptions are made for the RMSE's value of 0.098 , which is on the border of acceptability, as well as GFI (0.918) which almost passed the (>0.95) threshold (Hair et al., 2010).

The measurement models of both data sets show no validity issues, except for the Image factor of the Case170 data set, which has AVE of 0.480 that is slightly below the threshold of 0.5 (Hair et al., 2010). As previously stated, the Case-170 data set is specific, with over $10 \%$ of missing data. Therefore we can consider the value of AVE (0.480) to be acceptable, since it falls close to the threshold of 0.5 (Konecnik et al., 2007). The composite reliability or CR-values is greater than the threshold value of 0.7 (Hair et al., 2010), confirming reliability of the model. Discriminant validity is confirmed since Maximum Shared Variance (MSV) and Averaged Shared Variances (ASVs) are smaller than AVEs for both data sets. See Table 3. Therefore, we conclude that reliability, discriminant and convergent validity, are confirmed for both data sets (Hair et al., 2010).

TABLE 3. Measurement Model

\begin{tabular}{|c|c|c|c|c|c|c|c|}
\hline Variables & D & $\mathbf{F}$ & SL & GR & AVE & MSV & ASV \\
\hline & \multicolumn{7}{|c|}{ Case- 50} \\
\hline Awareness & AW & 1 & 0.676 & 0.864 & 0.685 & 0.545 & 0.545 \\
\hline Attractiveness & 1 & I & 0.752 & & & & \\
\hline Travel \& Tourism Competitive Index & 1 & I & 1.017 & & & & \\
\hline Economic Well-being (a) & SU & LO & & 0.709 & 0.547 & 0.545 & \\
\hline Environmental Well-being & SU & LO & 0.620 & & & & \\
\hline Ecological Footprint & SU & LO & 0.806 & & & & \\
\hline National Brand Strength & LO & LO & 0.908 & & & & \\
\hline Receipts per Arrival & LO & LO & 0.473 & & & & \\
\hline \multirow[t]{2}{*}{ Index of Economic Freedom } & LO & LO & 0.798 & & & & \\
\hline & \multicolumn{7}{|c|}{ Case-170 } \\
\hline Awareness & AW & 1 & 0.714 & 0.734 & 0.480 & 0.228 & 0.182 \\
\hline Reputation & 1 & I & 0.628 & & & & \\
\hline Attractiveness & 1 & I & 0.733 & & & & \\
\hline Human Development Index & SU & SU & 0.823 & .892 & 0.677 & 0.228 & 0.157 \\
\hline Economic Wellbeing & SU & SU & 0.668 & & & & \\
\hline GDP per Capita & SU & SU & 0.857 & & & & \\
\hline Ecological Footprint & SU & SU & 0.921 & & & & \\
\hline Receipts & LO & LO & 1.109 & 0.927 & .814 & 0.136 & 0.111 \\
\hline Arrival & LO & LO & 0.767 & & & & \\
\hline National Brand Value & LO & LO & 0.790 & & & & \\
\hline
\end{tabular}

D dimension of CABE (AW awareness; I image; SU sustainability; LO loyalty); F extracted factors; SL standardized loading; CR composite reliability; AVE average variance extracted; MSV maximum shared variance; (a) deleted after the discriminant test. 
TABLE 4. Standardized Solutions of Structural Model

\begin{tabular}{|l|l|c|c|c|c|}
\hline Dimension & Factors & Category & Case-50 & Case-170 & H-Testing \\
\hline Internal & CABE & HOF & 0.669 & & \\
\hline External & CABE & HOF & 1.104 & & \\
\hline Image & CABE & HOF & & 0.775 & $\mathrm{H} 1$ \\
\hline Loyalty & CABE & HOF & & 0.476 & $\mathrm{H} 1$ \\
\hline Sustainability & CABE & HOF & & 0.616 & $\mathrm{H} 1, \mathrm{H} 6$ \\
\hline Internal & External & LOF & 0.730 & 0.296 & $\mathrm{H} 1$ \\
\hline Image & Sustainability & LOF & & 0.478 & $\mathrm{H} 1, \mathrm{H} 3, \mathrm{H} 4, \mathrm{H} 5$ \\
\hline Sustainability & Loyalty & LOF & & 0.152 & $\mathrm{H} 2$ \\
\hline Awareness & Image & LOF & 0.680 & 0.716 & $\mathrm{H} 1, \mathrm{H} 2$ \\
\hline Attractiveness & Image & LOF & & 0.731 & $\mathrm{H} 1, \mathrm{H} 2$ \\
\hline Reputation & Image & LOF & & 0.628 & \\
\hline
\end{tabular}

HOF higher-order factor; LOF low-order factor; I\&M identity and meaning; R\&R response and relationship

Furthermore, the Case-50 data set shows high correlation (0.73) between the proposed Internal and External dimensions of the CABE model.. This suggests the existence of the higher-order factor, which in this case we assume to be the CABE (Byrne et al. 1995). In the higher-order evaluation, co-variations of the low-order factors are assumed to be explained by the higher-order factor. Therefore, the two low-level factors, Internal and External, are considered to be sufficiently explained by the higher-order factor, the CABE, see Table 4.

The evaluation of the Case-50 structural model confirms the existence of duality and importance of all proposed dimensions, confirming the split of the CABE model into Internal and External. The path coefficient of 0.730 suggests strong relationship between the Internal and External latent variables without suggesting multicollinearity issue. A significance of the CABE is reflected in the External (0.669) and the Internal (1.104) path coefficients. The role of Awareness (0.680) in defining the Image is also considered to be significant. Therefore, the results support the findings of the previous research studies that awareness contributes to stronger perception of a country's image. Therefore, the study confirms the proposed CABE model by confirming the strong relationship between the two, hierarchically ordered low-level components Internal and External. Further, the study confirms the existence of the general higher-order construct, the CABE.

On the other hand, the structural model of the Case-170 data set shows that the path coefficient between Image and Loyalty is only 0.296 , indicating that more factors, other than Image, are needed to induce Loyalty. The same applies for the Sustainability and
Loyalty variables for which the path coefficient of 0.152 confirms that sustainability itself cannot sufficiently explain loyalty. On the other hand, the Awareness elements, Attractiveness and Reputation, show a significant influence on Image, 0.716 and 0.628 , respectively. The analysis shows that, under assumption that there is a higher-order factor, such as the CABE, we have significant causal paths between the CABE on one side, and Sustainability, Image and Loyalty on the other. See Table 4.

Image (0.775) is the highest and the most significant dimensional factor of the CABE that confirms our H7 hypothesis as shown in Table 4. This proves the concept that Image is the core dimension in the CABE destination model. Next, Sustainability (0.616) is the second most important dimension of the CABE, followed by Loyalty $(0.476)$, which confirms that the elements of sustainability impact the country brand equity value and, if they are not factored in, the brand equity value could be underestimated.

In this study we see two different perspectives. One perspective is when the $\mathrm{CABE}$ elements are directly related to brand equity, and the other when the elements are viewed in the interrelation context with no reference to brand equity as a higher-order construct. The former supports Dinnie's nation brand equity model, suggesting that the synergy effect contributes to the CABE value.

Also, this point of view places sustainability as a top ingredient of the CABE value by confirming that Dinnie's (2008) national brand equity model provides the framework for measuring the dimensions. On the other hand, the interrelation view of the CABE components shows that loyalty is not strongly connected with both image and sustainability components, sup- 
porting the traditional concept that places image at the core of the country destination brand equity concept. With this formulation, we conclude that all our hypotheses are confirmed.

\section{SUMMARY}

The study confirms the existence of the significant relationship between the Internal and External dimensions of the proposed CABE model based on the Dinnie's national brand equity model. Also, the study confirms the causal relationship between destination awareness and destination image, as previously reported by (Pike et al., 2011; Chen et al., 2010; Kladou et al., 2014). This relationship between awareness and image plays a significant role in defining the CABE model from the point of how specific function awareness plays in describing brand equity of a country. In particular, as pointed by Gartner and Konecnik (2011), awareness is more significant for market penetration than for repeat market.

The Dinnie's (2008) national brand equity model is used as a foundation for the CABE model because, unlike Kelller's and Aaker's models, which are based on consumer perspective, allows for both perceptual and actual (historical) data to be used. Implications are that global data from all countries can be used in the study contributing to the universality of the analysis and ultimately to the global relevance of the CABE model.

In particular, the study shows a strong positive relationship between the image of a country as a destination and the elements of sustainability associated with that country, which, on one hand, suggests the positive influence of the attribute-based destination image on tourists' perception of the country's attractiveness (Yasin et al., 2007; Shahin et al., 2012; Moradi $\&$ Zarei, 2012). On the other hand, the results support Keller's (2013) position that image is a major component of the brand equity model. Similarly, the study confirms that the elements of sustainability have a significant impact on the overall CABE, confirming the previous findings (Belz, 2008; Belz et al., 2010; Konecnik et al., 2015).

Finally, the study confirms a strong relationship between image and loyalty; however, the study was not able to confirm the extent to which sustainability impacts loyalty. The relationship obtained from the analysis was relatively weak suggesting that there are circumstances and scenarios where sustainability doesn't contribute significantly to the country desti- nation loyalty. Some authors suggest that destination resources, including dimensions of sustainability, are quite heterogeneous and segment-specific, making the resonance between the segments and the overall relationship, with a country as a destination, more complex (Moeller, 2010). Thus, the concept of sustainability as a construct of the CABE requires more detailed understanding of a country's resources in order to be fully implemented.

Ideally, we would like to have a full set of countries participating in each index. However, due to difficulties in obtaining valid and reliable data from a number of countries, which depends on a country and the nature of the index, in reality, each index has a different number of observations. In our data set, the number of observations ranges from 51 for Reputation to 182 for Ecological Footprint.

On the other hand, in the 167-observation scenario (Case 170), the problem of missing data was even more pronounced. It caused the convergent validity issue to appear. Consequently, the model-fit turns out to be acceptable at the borderline. Moreover, the observed conclusions require further refinements by conducting more analysis in order to completely, rigorously and significantly confirm the proposed causality.

Furthermore, the research limitations ascend from the need to further improve the analysis of the CABE dimensions. Specifically, the operationalization of the Identity dimension of the country brand promise is omitted from the research on the grounds that no suitable variables from the dataset are identified. This suggests that more global indices are required in particular for operationalization of Identity as well as Awareness and Image constructs.

Next, the awareness components seem to be under-operationalized. The study uses only two indexes, Awareness (Travel Image) and Reputation (Reputation Institute) for the awareness construct. There should be more variables or global indexes to reflect all six different types of awareness forms for achieving better model-fit and more extraction constructs.

Also, the role of loyalty in the brand equity models of a country as a destination is not adequately covered by the research literature. A theoretical question still exists, asking that, if a potential visitor develops strong, favorable and unique associations towards a certain country, based on awareness and image levels, would that be enough for he or she to act on it?

Another limitation is operationalization of the global indexes from the secondary global sources. As the secondary data from global databases become more available, the more standardized, consistent 
and structural approach, supported by the literature, should be developed and used.

More research needs to be done to explain the relationship and the synergy effect between CABE and the associated dimensions and constructs. In particular, the synergy effect between the Identity, Sustainability, Loyalty, Image and Awareness should be explored in greater depth with inclusion of more global indexes with both perceptual and actual (historical) data.

Further limitations arise from the CABE model itself. Since the model is based on the Dinnie's NBEQ model it doesn't offer explanation how the inner constructs of the model are interrelated or structured. For example Keller's customer-based equity model offers a pyramid hierarchy. On one hand, this could present serious implications when it comes to analyzing the relationships between the constructs. On the other hand, it allows for extra flexibility in interpreting the relationships between the elements. The latter could be even more important in the initial stages of the model evaluation and development.

Finally, as suggested by Williams and Aitken (2011), the mutual dependence implies that the expected goals and desires are different because of the different access to resources; different values which serve as motivators to obtain profit or fulfill a social duty. Therefore, sustainability is dependent on judgments on what is acceptable and what is not, raising an issue of ethical discussion. In the context of modern on-line communication and use of social and other media, the global audience is at the moment's reach of any information, which is quite different from the traditional pool of customers. Today, everybody has a power to increase and decrease the value of brand equity of a country as a tourism destination, the power that only in the last decade has become available to the global audience.

The concept of the CABE, as proposed in this paper, points out that marketing, government and global organizations responsible for tourism marketing and reputation of a country as a brand should be aware of the proposed relationships and their implications as suggested by the model. Strategic programs should be employed to increase perceptions of image, awareness, sustainability and, consequently, loyalty dimensions, with the purpose to increase a positive, unique and favorable perception of a country as a brand. Marketing programs should put more emphasis on awareness, attractiveness, reputation, human development, and responsible management of natural resources, which in the short and long run could create positive perceptions of a country as a destination. The overall intent of the paper is to contribute to the comprehensive effort in defining the "Holy Grail" of the country brand equity research, the universal country brand equity model.

\section{References:}

1. Aaker, D. (1991). Managing Brand Equity. New York: The Free Press.

2. Aaker, D. (1996). Building Strong Brands. New York: The Free Press.

3. Alfsen, K. H., \& Greaker, M. (2007). From natural resources and environmental accounting to construction of indicators for sustainable development. Ecological Economics, 600-610.

4. Andersen, S. E., Ditlevsen, M. G., Nielsen, M., Pollach, I., \& Rittenhofer, I. (2013). Sustainability in Business Communication: An Overview. In S. E. Andersen, M. G. Ditlevsen, M. Nielsen, I. Pollach, \& I. Rittenhofer, Sustainability in Business Communication. Wiesbaden: Springer.

5. Anholt, S. (2007). Competitive Identity: The New Brand Management for Nations, Cities and Regions. New York: Palgrave Macmillan.

6. Aronczyk, M. (2013). Branding the Nation: The Global Business Identity. Oxford: Oxford University Press.

7. Ashworth, G., \& Kavaratzis, M. (2010). Towards Effective Place Brand Management. Northampton: Edward Elgar Publishing.
8. Belz, F. M. (2008). Marketing in the Age of Sustainable Development. In A. Tukker, System Innovation for Sustainability 1. Perspectives on Radical Changes to Sustainable Consumption and Production (pp. 114-135). Sheffield: Greenleaf.

9. Belz, F., \& Schmidt-Riediger, B. (2010). Marketing strategies in the age of sustainable development: Evidence from the food industry. Business Strategy and the Environment, 401-416.

10. Bianchi, C., Pike, S., \& Ling, I. (2014). Investigating attitudes towards three South American destinations in an emerging long haul market using a model of consumer-based brand equity (CBBE). Tourism Management, 42, 215-223.

11. Bigne, J., Sanchez, M., \& Sanchez, J. (2001). Tourism image, evaluation variables and after purchase behavior: inter-relationship. Tourism Management, 607-616.

12. Boo, S. Y., Busser, J. A., \& and Baloglu, S. (2009). A model of customer-based brand. Tourism Management, 219-231. 
13. Brand Finance. (2015). Nations Brands 2015. London: Brand Finance.

14. Buhmann, A., \& Ingenhoff, D. (2013). Advancing the Country Image Construct from a Public Relations Perspective: The Constitution of the County Image and its Effect on Travel Behavior. EUPRERA 2013 Congress, (pp. 1-17). Barcelona Spain.

15. Busse, C. (2010). A Procedure for Secondary Data Analysis: Innovation by Logistics Service Providers. The Journal of Supply Chain Management, 44-58.

16. Byrne, B., P., B., B., L., \& L., M. (1995). The Beck Depression Inventory: Testing and Cross-Validating a Second-Order Factorial Structure for Swedish Nonclinical Adolescents. Behavior Research and Therapy, 345-356.

17. Castellani, V., \& Sala, S. (2010). Sustainable Policy Index for Tourism Policy Development. Tourism Management.

18. Cevero, R. (2013, October 21). The FutureBrand Country Index: Country Brand Index 2012-13. Retrieved January 10, 2016, from http://www. futurebrand.com/images/uploads/studies/cbi/CBI_ 2012-Final.pdf

19. Chan, C., \& Marafa, L. (2013). A review of place branding methodologies in the new millennium. Place Branding and Public Diplomacy, 9 (4), 236-253.

20. Chen, J., \& Myagmarsuren, O. (2010). Exploring relationships between Mongolian destination brand equity, satisfaction and destination loyalty. Tourism Economics.

21. Chigora, F. (2015). Awareness Completes Brand Loyalty: Reality of Zimbabwe Tourism Destination. Business and Management Horizons, 60-69.

22. Crouch, G. (2011). Destination competitiveness: An analysis of determinant attributes. Journal of Travel Research, 27-45.

23. Dinnie, K. (2008). Nation Branding: Concepts, Issues, Practice. . Oxford: Elsevier.

24. Dietz, S., \& Neumayer, E. (2007). Weak and strong sustainability in the SEEA: Concepts and measurement. Ecological Economics, 617-626.

25. Dupeyras, A., \& MacCallum, N. (2013). Indicators for Measuring Competitiveness in Tourism: A Guidance Document. OECD Publishing.

26. Dwyer, L., Knezevic, C. L., Mihalic, T., \& Koman, M. (2014). Integrated Destination Competitiveness Model: Testing its Validity and Data Accessibility. Tourism Analysis.

27. Evans, A., Srezov, V., \& Evans, T. (2015). Measuring Tools for Quantifying Sustainable Development. European Journal of Sustainable Development, 291300.

28. Fabiutti, M., \& Tench, R. (2015, January). Are We Talking the Same Language? Challenging Complexity in Country Brand Models. Athens Journal of Business and Economics, 49-61.

29. Fetscherin, M. (2010). The determinants and measurement of a country brand: the country brand strength index. International Marketing Review, 466479 .
30. Ferns, B. H., \& Walls, A. (2012). Enduring travel involvement, destination brand equity, and travelers' visit intentions: A structural model analysis. Journal of Destination Marketing \& Management, 27-35.

31. FutureBrand. (2015). Country Brand Index 2014-15. Future Brand.

32. Gartner, W. C. (2014). Brand Equity in a Tourism Destination. Place Branding and Public Diplomacy 10 , 108-116.

33. Gartner, W. C., \& Ruzzier, M. K. (2011). Tourism Destination Brand Equity Dimensions: Renewal versus Repeat Market. Journal of Travel Research, 471481.

34. Gartner, W. (2009). Deconstructing brand equity. . In In Tourism Branding: Communities in Action. Bridging Theory and Practice, 1 (pp. 51-63).

35. Gerlach, A., \& Witt, J. (2012, March). Sustainability in the Context of Strategic Brand Management. Dissertation in International Marketing. Halmstad University School of Business and Engineering.

36. Gertner, D. (2011). Unfolding and configuring two decades of research and publications on place marketing and place branding. Place Branding and Public Diplomacy, 91-106.

37. GFN. (2015, November 13). Human Development Initiative. Retrieved November 18, 2015, from 2013-2015 Global Footprint Network: http://www. footprintnetwork.org/en/index.php/GFN/page/ fighting_poverty_our_human_development_ initiative/.

38. Gnoth, J. (2007). The structure of destination brands: leveraging values. . Tourism Analysis, 12(5/6), 345-358.

39. Go, F. M., \& Govers, R. (2011). International place branding yearbook 2011: managing reputational risk. Individual chapter's contributors. London: Palgrave Macmillan.

40. Grönroos, C. (2009). Marketing as promise management: regaining customer management for marketing. Journal of Business and Industrial Marketing, 24/5/6, 351-359.

41. Hair, J. J., Black, W., Babin, B., \& Anderson, R. (2010). Multivariate Data Analysis. A Global Perspective. 7th ed. Pearson.

42. Horng, J.-S, Liu, C.-H., Chou, H.-Y., \& C.-Y., T. (2012). Understanding the impact of culinary brand equity and destination familiarity on travel intentions. Tourism Management, 33, 815-824.

43. Im, H. H., Kim, S. S., Elliot, S., \& Han, H. (2012). Conceptualizing destination brand equity dimensions from a consumer-based brand equity perspective. Journal of Travel \& Tourism Marketing, 385-403.

44. Jaffe, E. D., \& Nebenzahl, I. D. (2001). National image and competitive advantage. Copenhagen: Copenhagen Business School Press.

45. Jansen, S. C. (2008). Designer nations: Neo-liberal nation branding - Brand Estonia. Social Identities, 121-142.

46. Kapferer, J.-N. (2004). The New Strategic Brand Management. London and New York: Kogan Page. 
47. Kavaratzis, M. (2010). Place branding: where do we stand? In: Ashworth, Gregory and Kavaratzis, Mihalis. Towards Effective Place Brand Management. Northampton: Edward Elgar Publishing.1-14.

48. Keller, K. L. (2013). Strategic Brand Management. In K. L. Keller, Strategic Brand Management Building, Measuring and Managing Brand Equity. Essex: Pearson.

49. Kerk, G. V. (2015, January 8). Is the world actually making progress towards sustainability? Retrieved October 25, 2015, from The Pelican Web: http://www. pelicanweb.org/solisustv11n02page2.html.

50. Kerk, G. v., \& Manuel, A. (2014). Sustainable Society Index 2014. The Hague: Sustainable Society Foundation.

51. Kladou, S., \& Kehagias, J. (2014). Assessing destination brand equity: An integrated approach. Journal of Destination Marketing \& Management, $2-10$.

52. Konecnik, M. R., Petek, N., \& Ruzzijer, M. (2015). Incorporating Sustainability in Branding: Journal of Brand Management, 1-20.

53. Konecnik, M., \& Gartner, W. C. (2007). Customerbased brand equity for a destination. Annals of Tourism Research, 400-421.

54. Kotler, P., \& Keller, K. L. (2012). Marketing Management. Upper Saddle River, NJ: Prentice Hall.

55. Lee, H., Ju-Pak, K.-H., \& Hong, M. (2015). Comparative Perspectives on Brand Value of Place Slogans: Analysis of Different Cities, States, and Countries. American International Journal of Social Science, 59-70.

56. Lindberg-Repo, K., \& Grönroos, C. (2004). . Conceptualizing communications strategy from a relational perspective. Industrial Marketing Management, 33(3), 229-239.

57. Lindemann, J. (2010). The Economy of Brands. New York: Palgrave Macmillan.

58. Lucarellli, A., \& Brorström, S. (2013). Problematizing place branding research: A meta-theoretical analysis of the literature. The Marketing Review, 65-81.

59. Maheshwari, V. (2010). Interpreting place branding and its significance in sustainable development $[\mathrm{PhD}$ Thesis]. Liverpool, United Kingdom: University of Liverpool.

60. Marruti, F., \& Tench, R. (2015). Are we talking the Same Language? Challenging Complexity in Country Brand Models. Athens Journal of Business and Economics, 49-61.

61. Meng, J. (2015). Sustainability: A Framework of Typology Based on Efficiency and Effectiveness. Journal of Macromarketing, 84-98.

62. Mihailovich, P. (2006). Kinship Branding: A Concept of Holism and Evaluation for the Nation Brand. Place Branding, 229-247.

63. Mittelstaedt, J., Shultz, C. J., Kilbourne, W., \& Peterson, M. (2014). Sustainability as Megatrend Two Shools of Macromarketing Thought. Journal of Macromarketing, 253-264.
64. Moeller, S. (2010). Characteristics of services - a new approach uncovers their value. Journal of services Marketing, 24/5, 359-368.

65. Moilanen, T., \& Rainisto, S. (2009). How to brand nations, cities and destinations: a planning book for place branding. London: Palgrave Macmillan.

66. Moradi, H., \& Zarei, A. (2012). Creating consumerbased brand equity for young Iranian consumers via country of origin sub-components effects. Asia Pacific Journal of Marketing and Logistics, 394-413.

67. Moran, D. D., Wackernagel, M., Kitzes, J. A., Goldfinger, S. H., \& Boutaud, A. (2008). Measuring sustainable development - Nation by nation. Ecological Economics, 470-474.

68. NFA. (2015). National Footprint Accounts. Oakland, CA: Global Footprint Network.

69. Nourry, M. (2008). Measuring sustainable development: Some empirical evidence for France from eight alternative indicators. Ecological Economics, 441-456.

70. Numbeo. (2016, April 2). Retrieved December 2, 2015, from Numbeo: http://www.numbeo.com/costof-living/

71. Parker, B. (2007). Evolução e revolução: da internacionalização à globalização. In S. Clegg, C. Hardy, \& W. Nord, Handbook de estudos organizacionais. Volume 1. São Paulo: Atlas.

72. Petrenko, P. (2015, May 29). Country-of-origin image effects on satisfaction and purchase intention in the industrial product for seafood products: A study of Norwegian, Chilean and Canadian salmon buyers. Aalesund: Aalesund University College.

73. Pike, S., \& Mason, R. (2011). Destination competitiveness through the lens of brand positioning. Current Issues in Tourism. 4(2): 169-182.

74. Rainisto, S. K. (2003). Success factors of place marketing: a study of place marketing practices in Northern Europe and the United States of America. [Ph.D. Thesis]. Finland: Helsinki University of Technology.

75. Ritchie, B. J., \& Crouch, G. L. (2003). The Competitive Destination: The Sustainable Tourism Perspective. Cambridge: CABI Publishing.

76. Ritchie, J. B., \& Crouch, G. I. (2010). A Model of Destination Competitiveness/Sustainability: Brazilian Perspectives. Revista de Administracao Publica.

77. Rocha, M. (2015, October 15). Brand Valuation to Unlock Business Growth. Retrieved January 8, 2016, from http://interbrand.com/views/insights-brandvaluation-a-strategic-brand-management-frameworkto-unlock-growth-for-your-business/

78. Rojas-Méndez, J. (2013). The Nation Brand Molecule. Journal of Product \& Brand Management

79. Ruzzier, M. K., \& De Chernatony, L. (2013). Developing and applying a place brand identity model: The case of Slovenia. Journal of Business Research, 45-52.

80. Schröter, T. Y., \& Schwekendiek, D. (2015). Understanding South Korea's Poor Nation Brand 
Image: A Content Analysis of Two Leading German Print News Media, 1948-2013. International Journal of Asia Pacific Studies, 115-135.

81. Seligman, M., \& Csikszentmihalyi, M. (2000). Positive Psychology. An Introduction. American Psychologist, 55(1), 5-14.

82. Sevin, E. (2011). Thinking about place branding: Ethics gof concept. Place Branding and Public Diplomacy, 155-164. DOI= 10.1057/pb.2011.15.

83. Shahin, A., Kazemi, A., \& Mahyari, H. K. (2012). How Consumer's Perception of Country of Origin Affects Brand Equity: A Case Study in Iran. Middle-East Journal of Scientific Research, 878-885.

84. Shimp, T. (2007). Integrated Marketing Communications in Advertising and Promotion, 7.ed. Ohio: South-Western/Thomson Learning.

85. Simkins, T. J., \& Peterson, M. (2015). Assessing the Value of a Societal-Level Sustainability Index for Macromarketing Research. Journal of Macromarketing, 1-18.

86. Sinclair, R. N., \& Keller, K. L. (2014). A case for brands as assets: Acquired and internally developed. Journal of Brand Management, 286-302.

87. SSF. (2014). Sustainable Society Index. Retrieved from Sustainable Society Foundation: http://www.ssfindex. com/about-ssf/

88. Szondi, G. (2007). The Role and Challenges of Country Branding in Transition Countries: The Central and Eastern European Experience. Place Branding and Public Diplomacy, 8-20.

89. UNDP. (2014). Human Development Report 2014. New York: United Nations Development Programme.
90. Vardar, N. (2013). Recent trends in global advertising practice, beyond the fundamentals. Retrieved October 2, 2013, from http://hstalks.com.ezproxy.leedsmet .ac.uk/

91. Viswanathan, M., Jung, K., Venugopal, S., Minefee, I., \& Jung, I. W. (2014). Subsistence and Sustainability: From Micro-Level Behavioral Insights to Macro-Level Implications on Consumption, Conservation, and the Environment. Journal of Macromarketing, 8-27.

92. Warnaby, G., \& Medway, D. (2013). What about the 'place' in place marketing? Marketing Theory, 345-363.

93. WEF, W. E. (2015). Travel and Tourism Competitiveness Report. Geneva: World Economic Forum.

94. Williams, J., \& Aitken, R. (2011). The ServiceDominant Logic of Marketing and Marketing Ethics. Journal of Business Ethics, 102, 439-454.

95. WWF, W. F. (2014). Living Planet Report. WWF International.

96. Xiang, Z., \& Gretzel, U. (2010). Role of social media in online travel information search. . Tourism Management, 31(2), 179-188.

97. Yasin, N. M., Noor, N. M., \& Mohamad, O. (2007). Does image of country-of-origin matter to brand equity? Journal of Product \& Brand Management, 38-48.

98. Zabkar, V., Brencic, M., \& Dmitrovic, T. (2010). Modeling perceived quality, visitor satisfaction and behavioral intentions at the destination level. Tourism Management, 31, 537-546.

99. Zakarevičius, P., \& Lionikaitè, J. (2013, December 3). An Initial Framework for Understanding the Concept of Internal Place Branding. Retrieved from Central and East European Central Library: www.ceeol.com

\section{Sažetak:}

\section{Model vrednosti nacionalnog brenda: Koncept održivosti}

\section{Milivoj Teodorović, Jovan Popesku}

U radu je predložen model vrednosti nacionalnog brenda u koji je uključen koncept održivosti radi određivanja vrednosti brenda destinacije. Predloženi model uključuje elemente održivosti, kao centralne dimenzije modela, i promoviše koncept "obećane održivosti” koji transformiše resurse destinacije u pozitivni doživljaj i iskustvo. Teorijski model je empirijski proveren globalnim sekundarnim podacima pri čemu je potvrđeno da nacionalni imidž održivost i lojalnost predstavljaju najvažnije elemente teorijskog modela. Istraživanje je pokazalo da rezultati ovog rada mogu imati uticaj na planiranje i implementaciju razvojne strategije destinacija.

Ključne reči: vrednost nacionalnog brenda, održivost, lojalnost brendu zemlje, brend imidž zemlje

\section{Kontakt:}

Milivoj Teodorović, student doktorskih studija milivoj.teodorovic.14@singimail.rs

dr Jovan Popesku, redovni profesor jpopesku@singidunum.ac.rs 